\title{
Stating the obvious: modal adjuncts in NATO press briefings
}

\section{Simon Eason}

\section{(2) OpenEdition}

1 Journals

\section{Electronic version}

URL: http://journals.openedition.org/asp/1764

DOI: $10.4000 /$ asp. 1764

ISBN: 978-2-8218-0384-8

ISSN: 2108-6354

\section{Publisher}

Groupe d'étude et de recherche en anglais de spécialité

\section{Printed version}

Date of publication: 1 October 2001

Number of pages: $39-50$

ISSN: 1246-8185

\section{Electronic reference}

Simon Eason, "Stating the obvious: modal adjuncts in NATO press briefings », ASp [Online], 31-33 | 2001, Online since 08 October 2010, connection on 20 April 2019. URL : http:// journals.openedition.org/asp/1764; DOI : 10.4000/asp.1764

This text was automatically generated on 20 April 2019.

Tous droits réservés 


\title{
Stating the obvious: modal adjuncts in NATO press briefings
}

\author{
Simon Eason
}

\section{Introduction}

1 In this article I wish to outline the possibilities for the exploration of evaluative meanings with particular reference to NATO discourse. The working hypothesis is that, as with any "propagandistic" text, there will be an abundance of evaluative lexico-grammatical features. More particularly, one might expect to find a high frequency of markers of the semantic dimension of Obviousness due to the fact that the speaker is seeking to establish the logical validity of his propositions. Such a dimension is often realized as Adjunct, in a variety of grammatical guises, and this paper will therefore focus on adverbs and other adverbial expressions.

In any exercise in discourse analysis, it is of the utmost importance to take into account the context of production of the texts in question. I will therefore begin by outlining the background to the production of the texts, which constitute the corpus of 40 press briefings given by NATO spokesman Jamie Shea during the Kosovo crisis. I will then detail the theoretical framework which underpins the study, before giving an account of three Adjuncts, of course, obviously, and as you know, which account for the major part of the expression of the semantic category in question.

\section{NATO discourse and the Kosovo crisis}

3 NATO's Operation Allied Force, a military response to Serbian attacks against Kosovar Albanians, began on 24 March 1999 and lasted for seventy-eight days. Throughout the campaign, the then NATO spokesman, Dr. Jamie Shea (now Director of Information and Press, NATO), gave daily press conferences, along with senior allied officers, at NATO headquarters in Brussels. The conferences were designed to achieve multiple objectives. During the campaign, NATO spokesmen had to face the challenge of attempting to satisfy 
the insatiable media demand for information while at the same time presenting their view of an effective air campaign. Indeed, it is essential to regard the press conferences as an integral part of the war effort. Press information is part and parcel of the framework of military Media Operations (MediaOps), which in turn are often associated with the military tools of Intelligence and Psychological Operations (PsyOps). The press conferences were broadcast live every afternoon, and followed closely in Yugoslavia itself.

4 A further objective was to present a united allied front within the nineteen-nation Alliance. Inevitably, there were disagreements between the governments of the member nations in terms of the tone and content of the message being sent out simultaneously, through the press conferences, to both allied populations and the Serbian enemy. After the tragedy at Djakovica, in which a tractor-load of refugees was mistakenly bombed by NATO aircraft, the British government felt that NATO was losing its grip on the media war. Prime Minister Tony Blair dispatched his own Press Secretary to Brussels in the person of Alistair Campbell (of "spin doctor" fame), in an attempt to "tighten up" the media campaign.

5 The arrival of Campbell in Brussels corresponded to an increased pace on the media front. The Media Operations Centre (MOC) was hurriedly inaugurated in Brussels, and it was decided that an additional off-camera press briefing, to be held every morning, would be necessary to supplement and prepare for the afternoon televised press conference. The morning briefings, instated as a response to a perceived weakness in the media campaign, will be the focus of this study.

6 The morning press briefings and the afternoon press conferences share the same basic structure (greeting, presentation of information, questions and answers), and it is probably reasonably safe to postulate the existence of a genre that we might label "pressconference". However, to my knowledge there have been few studies of this particular genre. The texts under study here are transcripts of the morning press briefings and, as such, are arguably of great political significance in so far as they represent the public record of the discourse of nineteen nations during a major and controversial military event. The question of transcription does of course pose a number of theoretical problems which I will not pursue here. Audio copies of the briefings have been obtained for purposes of comparison with the official transcriptions. The transcripts were copied into a single plain text file to facilitate a computer-assisted analysis.

\section{Systemic Functional Linguistics}

7 The theoretical backdrop to this analysis is broadly that of Systemic Functional Linguistics (SFL), a theory of language which revolves around the concept of language function, and which is particularly useful as a discourse analysis tool. Within a broader framework of social semiotics, this theory seeks to explicate the linguistic resources used by speakers in order to make meanings and achieve objectives. SFL takes its point of departure as the social context, and examines how language both has an influence on and is influenced by this context.

8 Following Halliday $(1978,1994)$, the contextual dimensions of a text can be identified according to three situational parameters: Field (the subject matter e.g. NATO air strikes), Tenor (the social roles and relationships between the participants e.g. journalist/ 
spokesperson), and Mode (the channel of communication, including distinctions between monologic/dialogic, spoken/written, written/written to be spoken etc.). The situational variables of Field, Tenor and Mode do not merely form a contextual background against which linguistic exchanges take place, but rather they determine the very nature of the text (Morley 1985: 47). The contextual dimensions of text have more generally been accounted for within the study of register.

The Systemic Functional model includes three semantic "metafunctions" which map onto the parameters of register. Firstly, the Ideational (or Experiential/Representational) metafunction concerns the meaning of the clause in the general sense, that is to say the propositional content. In SFL, ideational aspects of language have been accounted for primarily within the study of transitivity. The clause in (1) will serve as an example:

(1) Yesterday NATO forces conducted over 600 sorties during a 24 hour period.

Table1. Example 1: propositional content

\begin{tabular}{|l|c|c|c|c|}
\hline Yesterday & NATO forces & conducted & over 600 sorties & during a 24 hour period \\
\hline Circ: time & Actor & Material Process & Range & Circ: duration \\
\hline
\end{tabular}

10 In this clause the process conduct is, in this case, of the material type, which is to say that it encodes some action in the physical world viz., the movement of aircraft. NATO forces is encoded as the instigator of the action (Actor), while over 600 sorties, the Range, indicates the domain over which the process takes place (Halliday 1994: 146). The two circumstantial elements Yesterday and during a 24 hour period indicate the time and the duration of the process respectively.

11 The Interpersonal metafunction accounts for a second, parallel, type of meaning making. Here we are concerned with both speaker/hearer relations and also with the relationship between the speaker and his own message. In the former case we would examine speaker choices in the system of Mood, or use of vocatives, for example. As far as the speaker/ speaker message is concerned, the areas of modality and hedging have been studied, particularly within academic and scientific texts (e.g. Banks, 1994).

12 In terms of the interpersonal metafunction, our example (1) can be analysed as follows (see Table 2).

Table2. Example 1: interpersonal metafunction

\begin{tabular}{|c|c|c|c|c|}
\hline Yesterday & NATO forces & conducted & over 600 sorties & during a 24 hour period \\
\hline Adjunct & Subject & Finite+Predicator & Complement & Adjunct \\
\hline
\end{tabular}

In this case, the finite operator is fused with the predicate (absence of an auxiliary). The Subject ${ }^{\wedge}$ Finite order indicates selection of declarative mood, with the speaker (in this case the NATO spokesman) enacting the discourse role of giver of information. In assuming this role, the speaker naturally attributes to the hearer the corresponding role 
of receiver of information. The finite element is that which enables the negotiation of meaning through, for example, the use of question tags.

The textual metafunction concerns the text-enabling aspects of language and includes phenomena such as cohesion, theme/rheme, and information structure:

Table3. Example 1: textual metafunction

\begin{tabular}{|c|c|}
\hline Yesterday & NATO forces conducted over 600 sorties during a 24 hour period \\
\hline Theme & Rheme \\
\hline
\end{tabular}

In this case the speaker chooses the circumstantial as the point of departure (Theme), and the rest of the clause is set against this background (Rheme).

It should be clear from this multiple analysis of (1), that ideational, interpersonal, and textual meaning-making resources are simultaneously deployed. However, for the purposes of this study, the interpersonal aspects of text are of particular interest.

\section{Evaluation}

Scholars working within Systemic Functional Linguistics and allied fields of enquiry have come to use the term Evaluation as an umbrella term covering "the expression of the speaker or writer's attitude or stance towards, viewpoint on, or feelings about the entities or propositions that he or she is talking about" (Hunston \& Thompson 2000: 5). Current research into evaluation in text draws upon previous work on interpersonal aspects of language, carried out under banners as diverse as affect, appraisal, attitude, connotation, modality, point of view, style, and stance.

Appraisal theory, in particular, has attempted to map out the semantics of evaluation (see for example White 1999, and Martin 2000). In this model, three semantic domains are identified: Attitude, Engagement, and Graduation. Attitude concerns values (either positive or negative), emotion and affect (He's a hero, I admire him). Engagement pertains to the resources by which the speaker positions himself with regard to propositions. Such speaker stances include, for example, modals of probability (possibly), hearsay/ evidentiality (he alleged), expectation/ counter-expectation (predictably, amazingly). The third aspect of Appraisal, Graduation, deals with the regulation of the interpersonal force behind the utterance (slightly, somewhat, very).

Such a broad definition of evaluation necessarily encompasses a whole range of lexicogrammatical, textual, and pragmatic resources, including markers of modality, hedging and vagueness, adverbs and sentence adjuncts (fortunately, quite frankly, obviously), nouns ( tragedy, triumph), verbs (warplanes attack targets v. visit targets). A distinction is generally made between epistemic opinion regarding the proposition (probability), and affective opinion i.e. what is good (achieves the speaker's goals) versus what is bad (impedes the achievement of the speaker's goals). Adjuncts are often a vehicle for the different types of evaluative meaning outlined here. 


\section{Modal adjuncts}

20 At group level, adverbs and sentence adjuncts (adverbials) are, from a grammatical point of view, mostly an optional element in the clause and can be divided into three categories: Circumstantial, Conjunctive, and Modal, corresponding broadly to the three language metafunctions: Ideational, Textual, and Interpersonal (Bloor \& Bloor, 1995: 51). Within the category of Modal Adjunct (evaluative), Halliday (1994: 81) distinguishes further between Mood Adjuncts and Comment Adjuncts. Elsewhere, (see for example Thompson \& Zhou 2000: 123), such evaluative adverbs and sentence adjuncts are referred to as Disjuncts.

Modal adjuncts account for only a small proportion of sentence adverbials in English. Conrad \& Biber (2000: 63) suggest that while circumstantial adjuncts occur around 8000 times per 100,000 words, modal adjuncts occur between 200 and 700 times, depending on the genre. In the corpus of press briefings, evaluative adjuncts are realised by a number of grammatical forms including:

a) single adverbs:

(2) There probably are contacts, we know that, between the UCK and allies, but there is no contact, to my knowledge, between the UCK and the political or military structures of the Alliance.

b) prepositional phrases:

(3) So, yes, I did see the article, but I see no material proof to suggest that Russia is disengaging; in fact quite the contrary [...].

c) finite clauses: ${ }^{1}$

(4) On the second issue, yes there have been I think one or two HARM missiles which have strayed over the border into Bulgaria since the beginning of the operation [...].

d) adverb phrases:

(5) [...] without diplomacy force has no purpose but without the force that we are using I would not expect the diplomacy to have much of an impression on Milosevic quite frankly [...].

e) non-finite clauses:

(6) Doug, I have never seen a figure on casualties and to be frank with you I think it is something that is very difficult to know, I haven't seen an estimate either.

Adverbs, prepositional phrases, and finite clauses account for the majority of modal adjuncts (around 90\%).

A notoriously significant difficulty in the analysis of evaluative adjuncts resides in their categorisation on the semantic plane. Biber et al. (1999: 557-558) propose three semantic categories of stance adverbial: epistemic, attitude, and style. Epistemic stance adverbials include subcategories such as certainty or doubt (definitely), reality or actuality (actually), evidentiality (apparently), adverbs indicating limitations (typically), and hedges (roughly). Attitude stance adverbials indicate the speaker's attitude to the proposition as a whole ( 
unfortunately), and correspond roughly to Halliday's Comment Adjuncts. Finally, in Biber's categorisation, Style stance adverbials comment on the manner of speaking (frankly).

Halliday (1995: 49) outlines fourteen semantic categories for Modal Adjuncts; Lemke (1998) reduces these to seven evaluative dimensions which can be connoted positively or negatively: desirability (fortunately), probability (possibly), normativity (it is appropriate that), expectability (suprisingly), importance (significantly), seriousness (it is ironic that), and obviousness (of course). Other analysts propose a much less detailed categorisation. Hyland (2000:87) distinguishes simply between Hedges (modulation of the speaker's commitment to his statements), and what he calls Boosters - strategies that allow speakers "to express their certainty in what they say and to mark involvement and solidarity with their audience". Examples of Boosters given by Hyland include obviously and of course.

The plethora of categorisations and associated terminology can lead to confusion. The categorisations hitherto proposed for the evaluative dimensions of text clearly demand qualification, refinement, and discussion, but in this paper I wish to focus on the category of Obviousness, which encompasses Expectation in the Appraisal model and seems to be a well-established category in the analysis of the evaluative dimensions of English.

\section{Obviousness}

The plain text file containing the transcriptions of the morning press briefings was imported into a software package to assist with analysis. The evaluative adjuncts were tagged, and systems networks were developed within the software to facilitate the analysis of the adjuncts in terms of grammatical form, clause position, and semantic dimension. Even the most superficial of readings of the corpus leaves no doubt as to the abundance of adjuncts pertaining to the semantic category of Obviousness.

In a corpus of conversation of five million words, Conrad and Biber (2000: 69) report around 700 occurrences of stance adverbials per 100,000 words, across the semantic spectrum. In the corpus of morning press briefings (100,000 words), obviously, as you know, and of course alone total 480 occurrences (obviously 149, as you know 148, of course 183). Of course, caution must be exercised when comparing results with data from other genres. Indeed, I believe that in many cases, including that of Conrad and Biber, the fact the corpora are composed of extracts of texts rather than integral texts may well have some bearing on the results obtained. Within a given genre, different moves give rise to the deployment of varying lexico-grammatical features, and this must be taken into account when building corpora. Nevertheless, in terms of frequency, the results for the three adjuncts in question are clearly quite remarkable. Examples include:

(7) John, obviously we want to spare the inconvenience to the Serb people but clearly we have to go after the fundamental military objectives.

(8) And as you know, NATO countries always cooperate fully with international law because we are the people who promote and defend international law.

(9) So if you look at the daily toll of misery of a Yugoslav citizen, much more comes from the chronic misrule of 10 years under the Belgrade regime than the temporary inconvenience of NATO activities, even though of course any inconvenience is something that we regret, but that is the consequence of Milosevic's actions. 
It would appear that of course is one of the most common evaluative adjuncts, across genres. If we compare the frequency results for this adjunct with Conrad and Biber's findings, the results are even more striking. Figure 1 indicates occurrences of of course per 100,000 words in the morning briefings, and in three other genres.

Figure 1. Occurrences of of course

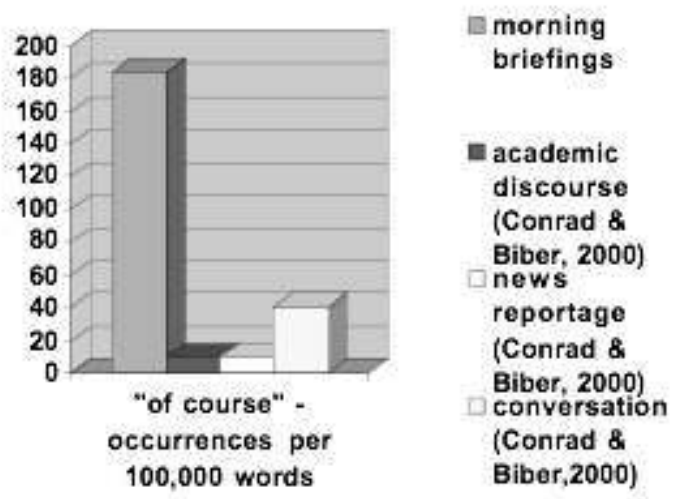

Adjuncts such as these can occur in various positions in the clause. Conrad and Biber (2000: 71-72) give clause positions as initial, pre-verbal, post-verbal, and final. Most of the adjuncts occur early in the clause, either as interpersonal theme or in some other prefinite position (see Figure 2). Of course, in many cases, where there is no auxiliary in the verbal group, the finite operator is fused with the verb and therefore post-finite corresponds to post-verbal.

Figure 2. Clause position of of course, obviously, and as you know (\% by position)

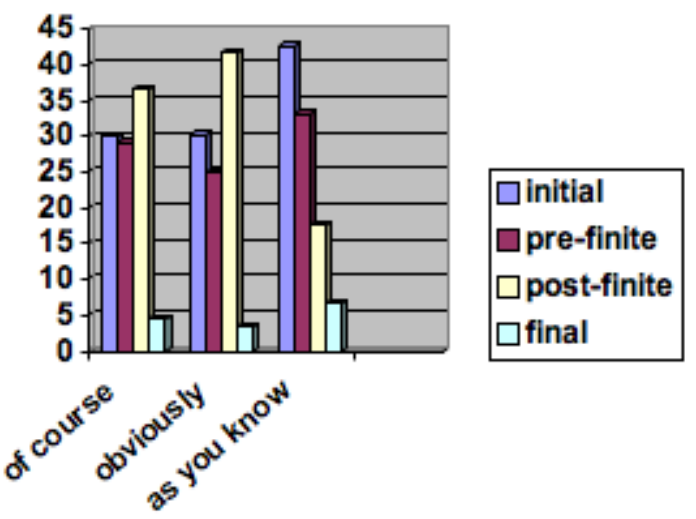

30 Few adjuncts appear in final position. This may be explained by the fact that the occurrence of adverbials early in the clause allows for more efficient processing (by the hearer) of the encoded evaluative semantics. Halliday (1994: 48-50) characterizes modal adjuncts as "typically thematic":

It is not difficult to see why modal and conjunctive Adjuncts tend to come at the beginning of the clause: if one of them is present at all, then in a sense it is a natural theme. If the speaker includes within the message some element that presents his or her own angle on the matter, it is natural to make this the point of departure: "I'll tell you what I think" (ibid.: 49-50). 

tone of the NATO press briefings. This last quote from Shea seems to echo the sentiments expressed by Tony Blair in an important speech made in Chicago on the eve of the NATO summit in Washington on the occasion of its $50^{\text {th }}$ anniversary. This speech was delivered on 22 April -a month into the Kosovo conflict, and just prior to Alistair Campbell's arrival in Brussels to bolster the media campaign. Tony Blair proclaims: "This is a just war, based not on any territorial ambitions but on values". In this speech, Tony Blair suggests that NATO intervention is inextricably linked to globalisation:

We are all internationalists now, whether we like it or not. We cannot refuse to participate in global markets if we want to prosper. We cannot ignore new political ideas in other countries if we want to innovate. We cannot turn our backs on conflicts and the violation of human rights within other countries if we want still to be secure.

These propositions are presented as self-evident, undeniable truths (but note the absence of overt signalling of Obviousness in Blair's discourse). Globalisation (internationalism) is 
perceived as an inevitable phenomenon (much as New Labour's "third way" is presented as the only viable political course -for a full account see Fairclough 2000).

Obviousness and occur throughout the clause, with a preference for thematic position. It has been seen that these adjuncts have a very high frequency when compared to texts from other genres. They should not be seen as examples of idiosyncrasy, but rather as markers of the mediation of a strong desire to persuade public opinion of the necessity of NATO intervention. Such adjuncts contribute to a strategy of persuasion by postulating the existence of shared knowledge between speaker and hearer and, in many cases, the use of such adverbials may be viewed as a resource for facilitating the acceptance of contentious Subject/Predicate relationships.

These adjuncts exemplify the phenomenon of propagation, whereby text is given evaluative texture through the repetition of markers of a particular evaluative dimension. Further analysis will be necessary to provide a more systematic account of the evaluative dimensions in NATO discourse, throughout the semantic spectrum. 


\section{BIBLIOGRAPHY}

Banks, David. 1994. "Hedges and how to trim them". In Brekke M., Ø. Andersen, T. Dahl \& J. Myking (eds.), Applications and Implications of Current LSP Research 2, Bergen: Fagbokforlaget, 587-592,

Biber, Douglas et al. 1999. Longman Grammar of Spoken and Written English. Harlow: Pearson.

Blair, Tony. 2001. "Doctrine of the international community". Speech to the Economic Club of Chicago, 22 April 1999, In Foreign and Commonwealth Office-News-Speeches, 23 February 2001, http://www.fco.gov.uk/news/speechtext.asp?2316.

Bloor, Thomas and Meriel Bloor. 1995. The Functional Analysis of English: a Hallidayan approach. London: Arnold.

Bruce, George. 2001. "Lessons of Kosovo: Government observations on the fourteenth report from the defence committee of session 1999-2000". In House of Commons Papers, 2000-01, 178, London: Stationary Office.

Conrad, Susan and Douglas Biber. 2000. "Adverbial marking of stance in speech and writing". In Hunston Susan and Geoffrey Thompson (eds.), Evaluation in Text: Authorial Stance and the Construction of Discourse. Oxford: OUP, 57-73.

Eggins, Suzanne. 1994. An Introduction to Systemic Functional Linguistics. London: Continuum.

Fairclough, Norman. 1989. Language and Power. New York: Longman.

Fairclough, Norman. 2000. New Labour, New Language?. London: Routledge.

Graham, Phil. (In press). "Predication and propagation: a method for analysing evaluative meanings in technology policy". TEXT.

Halliday, Michael. 1978. Language as Social Semiotic. London: Arnold.

Halliday, Michael. 1994. An Introduction to Functional Grammar 2nd. ed. New York: Arnold.

Hyland, Ken. 2000. Disciplinary Discourses: Social Interactions in Academic Writing. Harlow: Pearson.

Hunston, Susan and Geoffrey Thompson. 2000. Evaluation in Text: Authorial Stance and the Construction of Discourse. Oxford: OUP.

Lane, Harriet. 2000. "The man who sold the war". The Observer Review, 5 March.

Lemke, Jay. 1992. “Interpersonal meaning in discourse: value orientations”. In Davies Martin and Louise Ravelli (eds.), Advances in Systemic Theory: Recent Theory and Practice. London: Pinter, 82-104.

Lemke, Jay. 1998. "Resources for attitudinal meaning: Evaluative orientations in text semantics". Functions of Language 5-1, 33-56.

Martin, James. 2000. “Beyond exchange: Appraisal systems in English”. In Hunston Susan and Geoffrey Thompson (eds.), Evaluation in Text: Authorial Stance and the Construction of Discourse. Oxford: OUP, 153-175.

Morley, David. 1985. An Introduction to Systemic Grammar. London: Macmillan.

Shea, Jamie. 2000. “The Kosovo crisis and the media: Reflections of a NATO spokesman”. NATO's Nations and Partners for Peace 1, 39-46. 
Thompson, Geoffrey and Jianglin Zhou. 2000. "Evaluation and organization in texts: The structuring role of evaluative disjuncts". In Hunston Susan and Geoffrey Thompson (eds.), Evaluation in Text: Authorial Stance and the Construction of Discourse. Oxford: OUP, 122-141.

White, Peter. 1999. "Beyond interpersonal metaphors of Mood: Modelling the discourse semantics of evaluation and subjectivity". Unpublished conference paper, 11th EuroInternational Systemic Functional Workshop, Ghent.

\section{NOTES}

1. In the case of (4), the clause I think has epistemic value and makes explicit the source of the modality through the pronoun $I$. The clause functions as a modalising Adjunct - a function more usually associated with an adverb. This is a an example of what Halliday (1994: 340) has referred to as "grammatical metaphor". Following Eggins (1994: 181), we can see that such clauses are functioning metaphorically as Adjuncts by testing for tags. In the present case we would pick up the tag haven't there? (rather than don't I?), indicating that the subject of the clause is existential there, not $I$.

\section{ABSTRACTS}

Recent research in Systemic Functional Linguistics and allied fields of enquiry into the construction of evaluative meanings has underlined the need for large-scale corpus-based research across genres. This paper presents the results of an initial analysis of a corpus of offcamera press briefings, given by NATO spokesman Jamie shea during the military campaign in Kosovo in 1999. The focus of the study is Shea's use of adverbs and other sentence adjuncts such as "of course" and "as you know", which realise the semantic dimension of Obviousness, and occur in the corpus with a much higher frequency than in texts from other genres. An examination of the context of production of the discourse serves to underscore the speaker's determination to produce a convincing and persuasive text. Such a determination is encoded in part through evaluative sentence adjuncts. Adjuncts such as these contribute to textual cohesion and are illustrative of the resources employed by mediators to facilitate the acceptance of potentially contentious judgements and implications.

Les recherches récentes sur la construction du discours évaluatif, menées notamment en Linguistique Systémique Fonctionnelle (LSF), font apparaitre un besoin de travaux de recherche dans des genres variés, s'appuyant sur des corpus importants. Nous présentons ici quelques résultats d'une première analyse portant sur un corpus composé de transcriptions de points de presse, donnés hors caméra, par le porte-parole de l'OTAN, Jamie Shea, durant la campagne d'intervention militaire au Kosovo en 1999. Nous nous sommes plus particulièrement intéressé à l'emploi d'adverbes ou d'expressions adverbiales comme "of course » ou " as you know", qui réalisent la dimension sémantique de l'évidence, et apparaissent dans notre corpus avec une fréquence bien supérieure à celle que l'on constate dans les textes relevant d'autres genres. L'examen du contexte de production du discours permet de souligner la forte volonté du locuteur de produire un discours convaincant, qui emporte l'adhésion. Cette détermination est en partie 
encodée par l'emploi de locutions adverbiales de type évaluatif, qui contribuent à la cohésion textuelle et illustrent les ressources dont disposent les médiateurs pour faciliter l'acceptation de certains jugements et implications potentiellement contestables.

INDEX

Mots-clés: cohérence, discours évaluatif, évidence, locution adverbiale, métafonction linguistique

Keywords: coherence, evaluation, language metafunction, modal adjunct, obviousness

\section{AUTHOR}

SIMON EASON

Simon Eason est doctorant en linguistique anglaise au sein de l'ERLA (Équipe de recherche en linguistique appliquée), Université de Bretagne Occidentale, Brest. office@eason.info 